\title{
Wheat ripening dynamics in Uzbekistan for harvesting it in earlier periods
}

\author{
Komil Astanakulov ${ }^{*}$ \\ Tashkent Institute of Irrigation and Agricultural Mechanization Engineers, Tashkent, Uzbekistan
}

\begin{abstract}
At present, the results of research of the ripeness dynamics of cereal for harvesting it in the earlier periods in the condition of Uzbekistan. During the researches, quality indicators were studied of wheat sorts of middle and late ripening "Krasnodar-99" and "Kroshka" as well early ripening "Chillaki" in wax (biological) ripening and technical (complete) ripening periods and the grain that was harvested in early periods. It was known that the grain of wheat becomes empty by results of experiments if it is harvested 16 earlier than complete ripeness. When it is harvested 12 days earlier, the grain ripens more completely than the previous. However, its fullness does not become at enough level. If the cereal is harvested 8 days earlier than complete ripeness, namely when it is harvested in the wax ripeness period, the fullness of the grain does not become less than the fullness of the grain that is harvested after complete ripeness.
\end{abstract}

\section{Introduction}

The climate condition of Uzbekistan allows harvesting the crops 2-3 times a year. Especially, it is achieved for this by seeding the peanut, corn, rice-plant, potato, leguminous, and vegetables-melons after harvesting the wheat crop. They are demanded to plant earlier as possible for more harvesting by repeat plants. For this, the cereal should be harvested earlier than usual, namely in the period of wax ripeness. When the cereal is harvested earlier, the quality of flour and straw becomes high because the gluten, protein, and other food substances become optimal. The loss of grain by falling becomes low. One of the main factors for earlier harvesting of cereal is that the harvesting period should be constituted correctly by connecting to the cereal's ripeness dynamics. Therefore, observing the ripeness period of cereal in the condition of Uzbekistan and according to the result defining earlier harvesting period of cereal is important.

Many scientists in foreign countries have observed the ripeness dynamics of cereal plants and harvesting methods in their wax-ripeness period, they are F.M.Kanarev[1], Ya.A.Podiniesh[2], M.G.Penkin[3], A.Kuznetsov[4], Yu.N.Upkunov[5], E.V.Jalnin[6], A.A.Zangiyev[7], R.R.Allen[8], P.R.Philips[9], J.R.O’Callaghan[9], E.A.Smith, P.H.Bailey, G.W.Ingram [10], D.A.Pacey and M.D. Schrock [11]. In Uzbekistan N.K.Salikhov [12], K.A.Shovazov [13] and others have researched.

*Corresponding author: komiljon.astanaqulov@gmail.com 
As a result of above mentioned and other researches in some northern zones of the world where precipitation is high, and it is often cold weather (Canada, England, Russia, Ukraine, Baltic States, Sweden, and others), some methods have been suggested for preventing of losses of the cereal in an uncomfortable condition of weather, namely by harvesting the cereal early, in wax ripeness period, three phases, namely total biological crop or only grain part is reaped, and it is transported to the threshing floor, after drying, it is threshed, and the threshed grain is separated [14,15,16,17]. In this method, harvesting works are started 10-15 days before, and an earlier finishing opportunity is created.

Furthermore, P.Philips and J.O'Callaghan have created a mathematical model of cereal harvesting, and they received as main indicators the moisture in ripeness period of grain and its changing after raining [9].

R.T.Schuler, N.N.Radokowski and H.L.Kuchera in Northern Dakota (USA) have defined that the grain losses of barley are 5,3 per cent, in wheat, the losses make up 3,6 per cent. As a result, the cereal is not threshed completely during the harvesting by the combine, and the grain is not separated from stalk and ear when the moisture of grain is high [18].

E.A.Smith, P.H.Bailey, and G.W.Ingram have researched the prediction of the crop's moisture level in the overall condition in ripeness period of barley and wheat [10]. They have developed an empiric model that describes the changing of grain moisture according to the temperature of weather on harvesting days, air moisture, and time by using a drying equation.

D.A.Pacey and M.D.Schrock in Kansas state have researched about wheat harvesting by combines; they defined that when the grain moisture declines from 15 per cent, the grain losses and damaging rise and they recommended that the grain moisture should be between 15-20 per cent when the cereal is harvested by combine [11].

C.Sorensen, P.Stacey, P.O.Kiely, B.Rice, F.Mara, J.Darby, L.Caddick have defined that when the cereal is harvested early at high moisture, total crop increases and the quality indicators of the grain are high; however, by this method, it is mentioned that using the coefficient of combines makes up 21-36 per cent and it is ineffective [19,20,21].

The research mentioned above shows that the cereal is not harvested at high-level moisture by combined harvesters. Besides, there is no opportunity to harvest the cereal early by combine; when they are used in some areas, energy and other expenses increase. Therefore, using suitable technologies for this harvesting condition is optimal for harvesting earlier cereal, namely in the wax ripeness period.

However, in the condition of Uzbekistan, the ripeness dynamics of cereal, physicalmechanical indicators of cereal, and its grain that are harvested in early periods have not been studied completely enough. Therefore, we carried out experiments for defining those indicators.

\section{Methods}

These experiments were carried out around projects with together Scientific-Research Institute of grains and beans to the method GOST 31345-2007 and GOST 20915-2011 [22, 23].

Researches were carried out by late ripened sort of wheat "Krasnodar-99" and "Kroshka" as well early ripened sort "Chillaki". The taken results were treated, their statistical amounts (average value Mave, average square declination $\pm \sigma$, coefficient of variation $\mathrm{V}$ and others) were defined [24, 25].

\section{Results and Discussions}


Results the changing of ripeness dynamics between 10th of May and 9th of June in sort "Krasnodar-99" of wheat showed that (figure 1), the grain moisture changed from 68,6 to 18,3 percent between that period, creamery period of grain went on from 10th of May to 24th of May and made up 10 days, dough period of the grain continued from 25th of May to 29th of May and involved 5 days; wax ripeness period of grain, namely declining from 40 percent of moisture began on 30th of May, it reached on 18,3 percent on 9th and ripened completely. The mass of 1000 pieces of grain increased sharply from 26,8 gram to 64,6 gram between 10th of May and 20th of May, between 20-26 of May that index declined significantly from 64,6 gram to 60,2 gram, maximal amount, namely 64,6 gram was observed on the 20th of May.

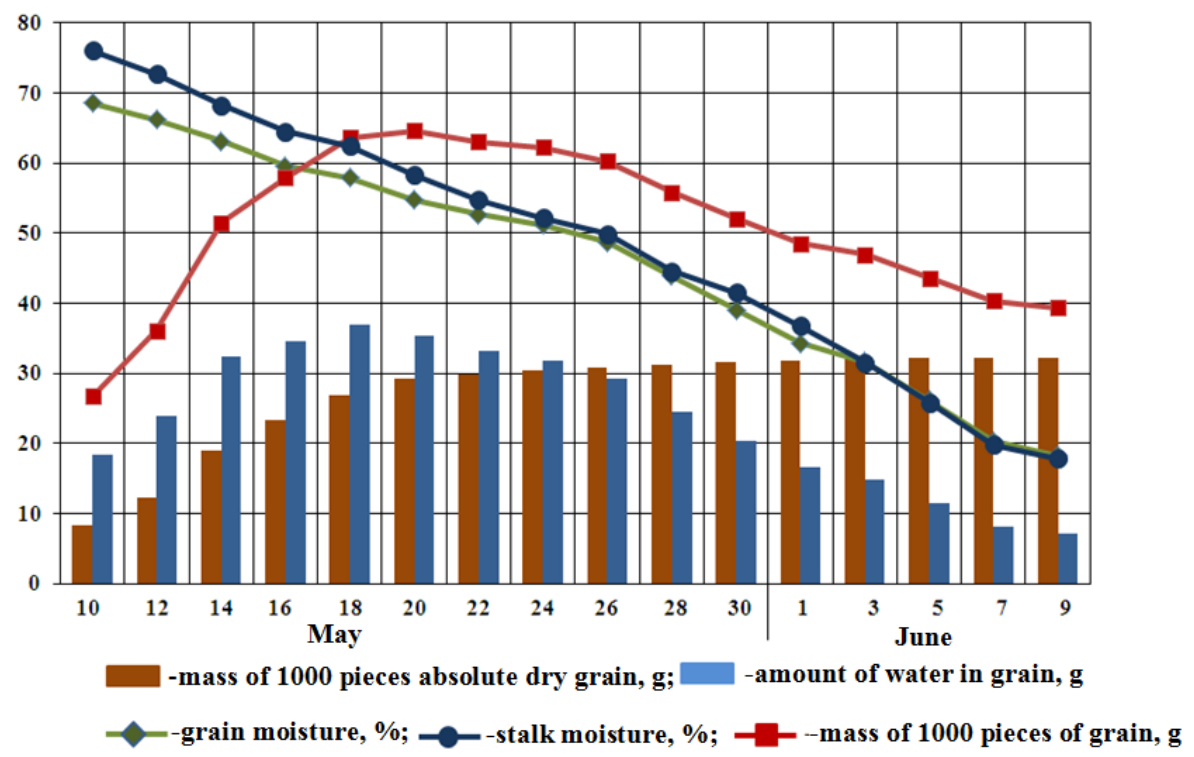

Fig. 1. Changing dynamics of moisture of the grain and stalk as well of mass of the grain in vegetation period in the sort "Krasnodar-99" of wheat.

Mass of 1000 pieces of grain decreased sharply from 60,2 gram to 40,4 gram between 26th of May and 7th of June; after ripening completely, the index almost did not change. In the period of wax ripeness of grain, the mass of 1000 pieces of grain constituted an average 52,1 gram. Also, while the mass of 1000 pieces of grain increased, the wet matters in it rose from 18,4 gram to 36,9 gram too, then a slight decrease was observed. In that period, the amount of dry matter in grain rose dramatically and reached from 8,4 gram to 26,8 gram. When grain moisture was 50 percent wet and dry, matters in it were equal; after decreasing the moisture of grain from 50 percent, the dry matters in it rose; however, a stable decrease of moisture was observed. When the grain starts to ripen as wax ripeness, there was of insignificant increase in the number of dry matters in it until completely ripening. It was just about 2-3 percent.

So, after the grain is formed, 1000 pieces of grain increase until exactly time then decreases. The amount of moisture in grain rises at first then falls respectively to the mass of 1000 pieces grain, the amount of dry matters in grain lifts, last 8-9 days it does not change. It takes 8-9 days from wax ripeness till complete ripeness, which means that cereal might be harvested earlier than that days.

The same experiments were performed by sorts of "Kroshka" and "Chillaki" (figure 2). 


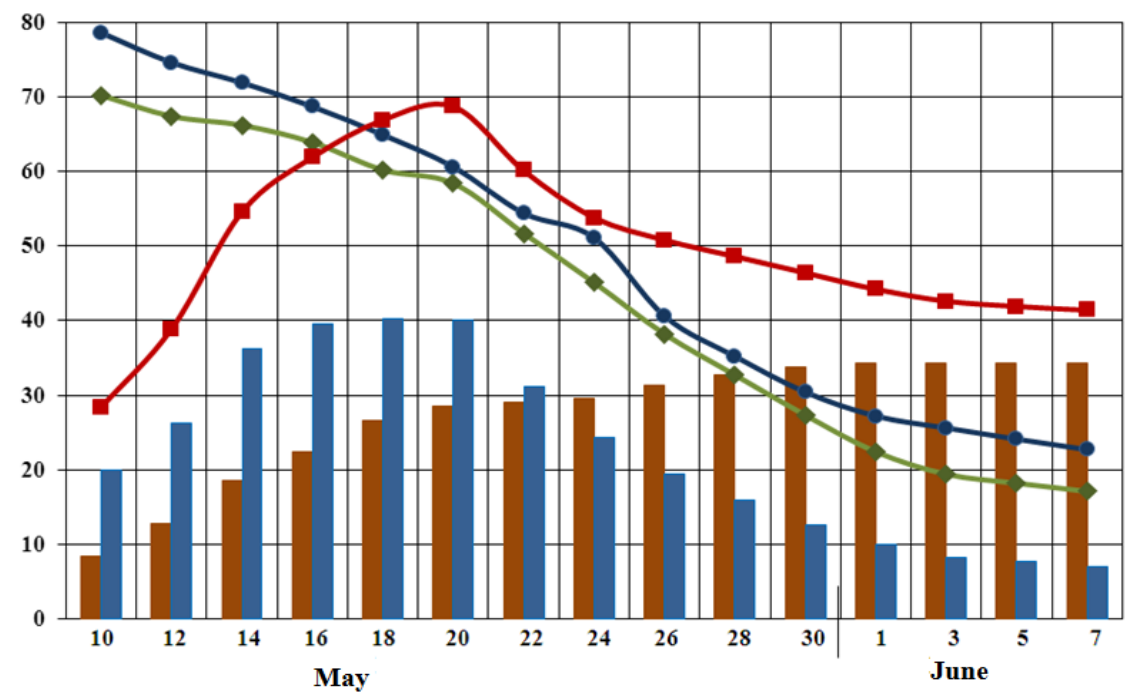

a - sort "Kroshka"

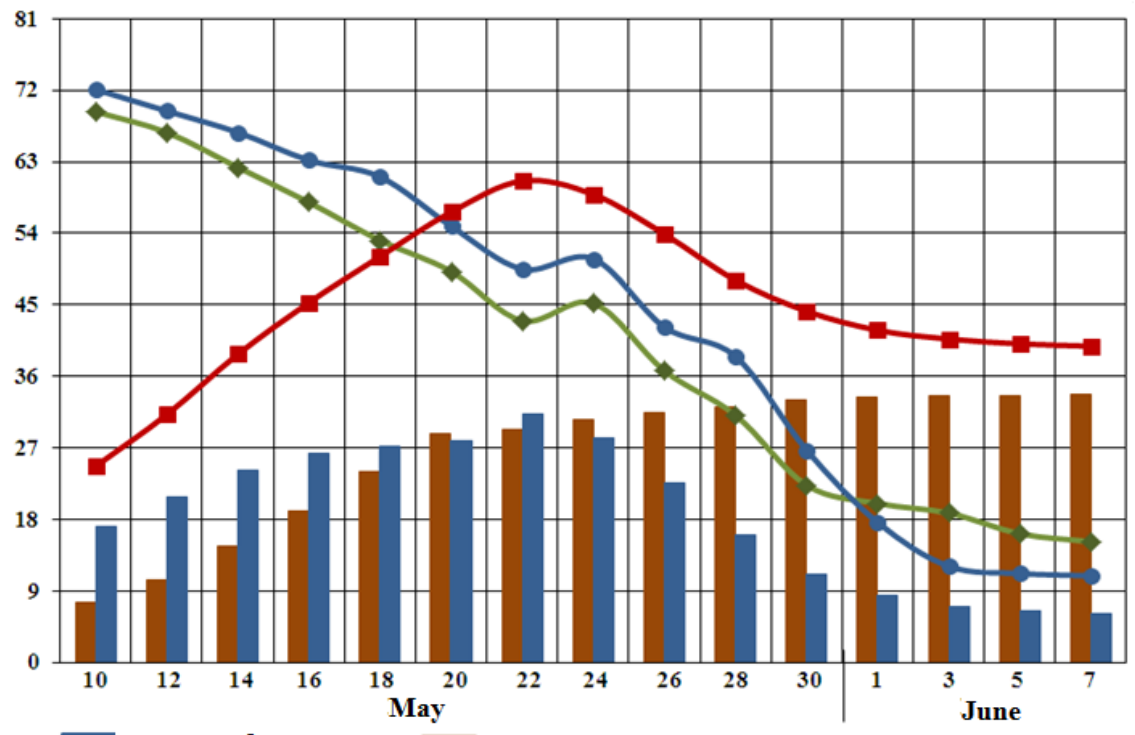

-amount of water, g; -mass of 1000 pieces absolute dry grain, $\mathrm{g}$

- -grain moisture, $\%$; - -stalk moisture, $\%$; - -mass of 1000 pieces of grain, g

b - sort "Chillaki"

Fig. 2. Changing graph of moisture of the grain and stalk as well the grain mass in sorts "Kroshka" and "Chillaki" of wheat.

The moisture of grain decreased from 70.2 percent to 17.1 percent while the moisture of stalk fell from 78.6 percent to 22.7 percent in the sort of "Kroshka" between 10th of May and 7 th of July, sharply changing of moisture was observed in 14-28 of May. In that period, the moisture of grain and stalk decreased almost two times, namely from 63.9 and 68.7 percent to 32.7 and 35.6 percent. The moisture of grain and stalk changed slowly in the period of 30th May and 7th July. 
In sort "Chillaki," the moisture of grain decreased from 69.3 percent to 43.0 percent while the moisture of stalk fell from 72.1 percent to 49.5 percent between 10-22 of May, because of the influence of the rain on 23rd of May, the moisture increased to 45.2 and 50.8 percent (2nd figure, b). However, next days, namely between 24th of May and 7th of June, the decreasing the moisture of grain from 45.2 percent to 15.2 percent was observed while the moisture of the stalk fell to 10.9 percent.

The period of wax ripeness to complete ripeness (grain moisture was between 36.718.8) was from 26th of May to 3rd June, it consisted of average 8 days. Also, in sort "Chillaki" after complete ripening of grain, the stalk moisture decreased more than the moisture of grain.

In the period of 10th of May to 3rd of June, the mass of 1000 pieces of grain increased, it goes on to increase until dough period, the index decreases from the period of dough to complete ripeness (2nd figure, a and b). In the samples taken on 20-22 of May, the mass of 1000 pieces of grain mad up 68.7 and 60.6 gram; on 22-24 of May, this index increased and made up 58.9 and 60.1 gram. Between the period of 26th of May to 3rd of June, the mass of 1000 pieces of grain decreased from 50.8 and 53.9 gram to 40.7 and 42.6 gram. In this period, the moisture of grain decreased from 38.2 and 36.7 to 19.4 and 18.8 percent, respectively.

In the sorts "Kroshka" and "Chillaki" of wheat, the mass of 1000 pieces of grain increased until grain becomes dough, decreased from wax ripeness to complete ripeness; after complete ripeness, it did not change.

Also, during the experiments changing of mass of 1000 pieces of grain was observed in the drying period of reaped cereal in different ripeness periods of grain (Figure 3).

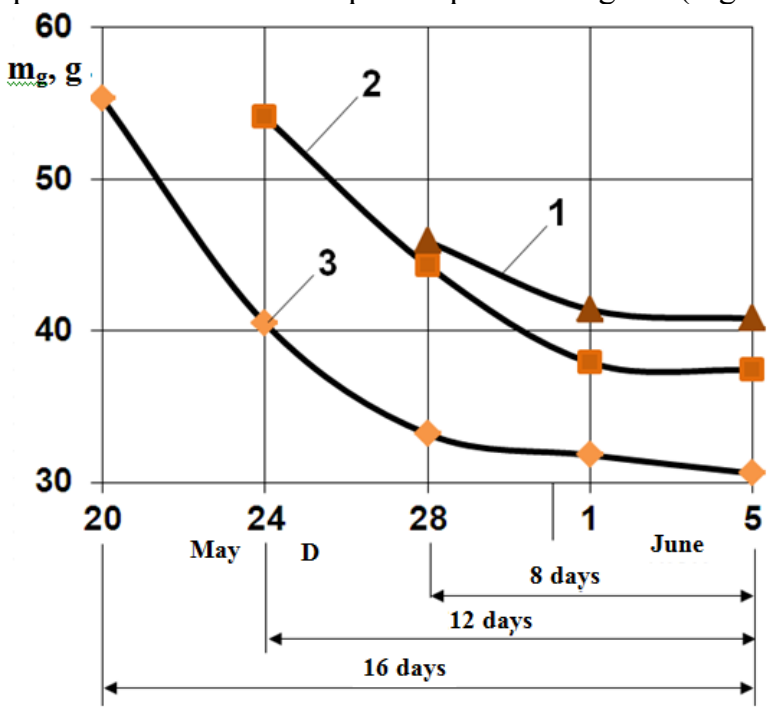

Fig. 3. Changing graphs of the mass of 1000 pieces of grain of the cereal in drying period that was reaped in different periods.

The cereal was reaped 8 days, 12 days, and 16 days earlier than the harvesting period at 1 st, 2 nd, and 3rd trends, respectively.

In that period, the cereal was reaped 16 days before ripening, then the mass of 1000 pieces of the grain of that cereal made up 30.6 gram when the moisture of the grain decreased from 18 per cent, after technical ripening, in cereal that was reaped 12 days before the mass of 1000 pieces of grain made up 37.4 gram. The mass of 1000 pieces of the grain of 
complete ripened made up 40,8 gram in cereal that was reaped 8 days earlier than complete ripeness.

\section{Conclusion}

It was known that the grain of wheat becomes empty by results of experiments if it is harvested 16 earlier than complete ripeness. When it is harvested 12 days earlier, the grain ripens more completely than the previous. However, its fullness does not become at enough level. If the cereal is harvested 8 days earlier than complete ripeness, namely when it is harvested in the wax ripeness period, the fullness of the grain does not become less than the fullness of the grain that is harvested after complete ripeness. The wax ripeness period of the grain appears: grain becomes in yellow completely, it is pressed by nail, but it does not become like dough. Stalk becomes yellowish, and lower leaves dry.

\section{References}

1. F. M. Kanarev, International agricultural journal. Moscow, 6 (1987)

2. Ya. Podiniesh, E. K. Lachgalvis, D. E. Viyesturs, Mechanization and electrification of agriculture. Moscow, 8 (1983)

3. M. G. Penkin, Collection scientific works AIM (Moscow, 1987)

4. A. Kuznetsov, Agromechanist. Moscow, 12 (1991).

5. Yu. N. Upkunov, Technological and technical providing harvesting the grain with treating biological crop on stationary in requirement of Eastern Siberia: Dis. ...D.Sc. (Novosibirsk:, 1995)

6. E. V. Jalnin, Technics in agriculture. Moscow, 6 (1999)

7. A. A. Zangiyev, Optimization parameters and regimes the work of aggregate for harvesting cereal crops on industrial-streamed technology (M.: Informagrotex, 1996)

8. R. R. Allen, TRANSACTIONS of the ASAE, 31 (1988)

9. P. R. Philips, J. R. O’Callaghan, Journal of Agricultural Engineering Research, 19 (1974)

10. E. A. Smith, P. H. Bailey, G. W. Ingram, Journal of agricultural Engineering Research, 26 (1981)

11. D. A. Pacey, M. D. Schrock, Harvesting wheat (Kansas state University, 1985)

12. N. K. Salixov, K. T. Shokirov, Counting work UzMEI (Yangiyul: UzMEI, 1996)

13. K. Shovazov, Creating the implement that is feeder the collected cereal by reaping and substantiation its sizes: Dis. Can. Tech. Sc. (Yangiyul: UzMEI, 2004)

14. I. Geydebrext, Technics and equipment of village. Moscow 4 (2006)

15. http://www.home.cc.umanitoba.ca McLeodWhole. (2015)

16. A. G. Bashtovoy, Abstract of dissertation ... DSc. (Blagoveshensk: DalGAU, 2008)

17. A. N. Lejenkin, Abstract of Diss. ...DSc. (M.: MGAIU after named Goryachkin, 2008)

18. R. T. Schuler, N. N. Radokowski, H. L. Kucera, Grain and forage harvesting. Proceedings of the First International Grain and Forage Conference (Iowa State University, Ames, Iowa, USA: Published by American Society of Agricultural Engineers. - Michigan , 1977) 
19. C. Sorensen, Agricultural Engineering International: the CIGR Journal of Scientific Research and Development. Manuscript, 5 (2003)

20. P. Stacey, P. O’Kiely, B. Rice, F. P. O’Mara, Irish Journal of Agricultural and Food Research, 42 (2003)

21. J. A. Darby, L. P. Caddick, CSIRO Entomology. TechnicalReport, 105 (2007)

22. GOST 28301-2007, Combine harvesters. Testing methods (Tashkent.Uzstandart, 2007)

23. GOST 20915-2011, Testing agricultural technics. Methods and requirements of testing (Moscow. Standartinform, 2013)

24. A. I. Kobzar, Applied mathematical statistics (Moskow: Phys Mathlit, 2006)

25. D. D. Wackerly, W. Mendenhall, R. L. Scheaffer. Mathematical Statistics with Applications Thomson Higher Education. Davis Drive Belmont, (2008) 